\title{
Study On Financial Management Objectives of Electric Power Enterprises under the New Economic Norm
}

\author{
Shuo Feng \\ School of Economoic Management, North China Electric Power University, Baoding 071000, China \\ fengshuozhenguan@qq.com
}

\begin{abstract}
The financial management objectives is the result of the enterprise financial management activity and the basic standard to evaluate the enterprise financial activity. It is very important to establish a reasonable financial management objective in theory and practice. In this paper, the objective of financial management of Chinese electric power enterprises under the new economic norm is studied and analyzed.
\end{abstract}

Keywords: new economic norm; financial management objectives; electric power.

\section{Introduction}

Economic new normal is the symmetry of the economic structure, the economic sustainable development, including the sustainable economic growth. Economic new normal is to emphasize the structure of the steady growth of the economy, rather than the total economy. It focuses on the symmetric state of economic structure and the sustainable development on the basis of symmetry, and not only the GDP, Real GDP per capita growth and the maximum of economic scale. Economic new normal is to use growth to promote development, with the development of growth to promote growth.

With the development of the socialist market economy and the promotion of the reform of electric power system, the power supply enterprise has made great progress. However, the financial management level of power supply enterprises under the new economic situation still needs further improvement. Financial management is the core of enterprise management, enterprise survival and development of the fundamental. Sustainable development of power supply enterprises must determine the reasonable financial management objectives, in order to achieve the maximum of enterprise value.

\section{The Main Content of Financial Management Objectives}

In the environment of socialist market economy, the financial management of electric power enterprises is a way to coordinate the economic interests of all parties concerned. Request for service object will show a pattern of diversity and the role of modern financial management of power enterprise is in many aspects, the objective of financial management is not the only, the combination of these factors, I think under the present market economy environment, electric power enterprise financial management objective realization due by three form:

Improving the economic benefit of power enterprise target. To improve the economic benefit of power enterprise is the core of financial management objectives. Because there is no economic benefits, there is no profit. There is no profit, there is no capital preservation and appreciation, and there is no profits and power enterprise value maximum.

Improving the competition ability of electric power enterprises. In order to improve the competitiveness of power enterprises, it is to continuously improve the operatng ability, earning power and debt-paying ability of the financial management objective system of power enterprises. Operating ability according to changes in the external market environment, the ability of rational allocation of the factors of production. It has a decisive influence on the sustainable growth of profitability and the continuous improvement of the debt-paying ability. Earning power ability is the ability for enterprises to earn a profit, it is base of debt-paying ability; debt-paying ability is electric power enterprise repayment ability of all due debts. Power enterprise owners, creditors, operators and 
other relevant aspects of the three are very concerned about the ability, the power enterprise only with these three capabilities, can be in an invincible position in the market competition.

\section{Selection and Significance of Financial Management Objectives of Modern Electric Power Enterprises}

The maximum of enterprise value is in line with the national conditions. Compared with other developed countries, enterprises should pay more attention to the actual interests of stakeholders and the rights of the parties; pay more attention to the interests of the parties; more emphasis on the accumulation of social wealth and the common prosperity of the people. In addition, China's current securities market is still in a weak state, if one-sided emphasis on wealth maximum, it will lead to short-term corporate behavior, the risk increases.

The maximum of enterprise value is in line with China's current property rights system, which is conducive to the establishment and improvement of modern enterprise system in our country. With the development of society, the enterprise will become a member of the whole social group. Therefore, enterprises must take into account the interests of the main interests of property rights and other stakeholders. The maximum of enterprise value is to make the cake bigger and guarantee the share of the interests of all parties concerned, and to meet the inherent requirements of the property rights system.

The maximum of enterprise value is in the long-term interests of the enterprise's sustainable development. Maximum of enterprise value no longer emphasizes enterprise current micro economic interests, pay more attention to the micro economic interests and macro-economic interests coordination; more emphasis on credibility, focus on corporate image building and promotion, pay more attention to improve product quality and after-sales service, maintain the long-term stability of the enterprise sales revenue growth.

The maximum of enterprise value overcomes the defect of Maximum of Shareholders Wealth, and realizes the shareholde's benefit to the greatest extent. Today, the right of shareholders must be restrict by the rights of other stakeholders. Only in the participation and efforts of all parties, it is possible to reflect the value of the business value of the cake bigger. Therefore, it is necessary to consider the value of other people to maximize the value of the value maximum of the value of the power enterprise to maximize the value of the pursuit of wealth.

\section{Problems Existing in the Financial Management Objectives of Power Supply Enterprises}

Profit maximum has the following hard to solve problems. No consideration of the time value of funds; Does not consider the relationship between input and output, is not conducive to comparison. Without taking into account the risk, the enterprise will be the pursuit of maximum profit, and bear too high risk. Profit maximization will produce short-term behavior, do not consider the long-term development of enterprises. The determination of the amount of profit is influenced by the choice of accounting policy, which is difficult to reflect the real economic benefits of enterprises.

There is the following problem of earnings per share maximum. Did not consider the time value of funds and risk factors; cannot avoid the short-term behavior of enterprises. Earnings per share is inversely proportional to the amount of share capital. If the company simply in order to pursue the maximum profit per share, while reducing the share capital increase in debt, the enterprise capital structure will lead to an imbalance in the financial situation, and even the financial crisis.

\section{Suggestions on the Financial Management Objectives of Power Supply Enterprises under the New Economic Norm}

With the deepening of economic and electric power system reform, the appropriate choice of enterprise financial management objectives has a direct impact on the survival and development of 
enterprises. The choice of financial management objectives should be considered in the following aspects.

Objectives of Corporate. Survival is the premise objectives of the power enterprise, the basic conditions of a charge to close the branch, the two to maturity. Which requires financial management fully consider the risk factors, reasonable arrangements for the electric power enterprise's debt ratio, to ensure the stability survive of electric power enterprises ; development is the core of electric power enterprises, power enterprises development concentrated expression for the expansion of income, which requires financial management can effectively raise the development funds of the electric power enterprise; the benefit is the ultimate objective of the enterprise and profit only, just have the survival value. This requires the financial management of the effective financial instruments. Reasonable arrangement of capital structure improve the earnings per share and the market value of electric power enterprises. The objectives of the electric power enterprise determines that the financial management objectives should be the maximum of the value of the electric power enterprise.

The economic system and the performance evaluation index. In today's economic globalization, power companies and more than one interest group. This requires the power enterprise financial personnel should not only consider the time value of funds, but also consider the risk of compensation. Not only consider the owners interests, but also considere the interests of relevant interest groups. Assuming corresponding social responsibilities, such as the protection of ecological balance, to prevent the pollution of the environment, support for public welfare, etc, so as to improve the electric power enterprise's reputation and visibility, enhance the comprehensive value of power enterprises.

\section{Summary}

Choose and determine the power supply enterprise financial management objectives, can mobilize the economic interests of the main body to participate in the enterprise financial management of the initiative, and encourage them to complete the enterprise's financial management objectives and efforts. At the same time, it will be bound to the economic behavior of the economic interests of enterprises, so as to meet the common requirements and the overall interests under the new economic norm.

\section{References}

[1] Jing Ming1. Project financial management problems and Countermeasures of electric power enterprise [J]. China Town and village enterprise accounting. 2015 No. 11.

[2] Dong Linqiang1. Analysis of the current situation of the financial management of the thermal power enterprises in China [J]. (Academic Edition). 2015 NO.20.

[3] Yu Yu1. Application of risk control method in the financial management of power system [J]. Enterprise technology development. 2014 NO.30.

[4] Chen Ying1. The strategy of financial management of electric power enterprises [J]. Modern economic information. 2012 NO.21.

[5] Sun Fangfang1, Yang Zhiguo2. An analysis of the current situation and development strategy of financial management in power enterprise [A]. "Decision making Forum -" the thesis collection (down) [C]. 2015

[6] [6] Liao Jie1. On the financial management of power enterprises to deal with [J]. Financial sector (Academic Edition). 2012 NO.28. 